\title{
Wor, the Traditional Biak Folksongs: A Study of Their Metaphorical Expressions
}

\author{
Reimundus Raymond Fatubun ${ }^{1} \&$ Markus Ricky Rumansara ${ }^{2}$ \\ ${ }^{1}$ Department of Languages and Arts, Faculty of Teacher Training and Education, Cenderawasih University, Papua, \\ Indonesia \\ Correspondence: Reimundus Raymond Fatubun, Department of Languages and Arts, Faculty of Teacher Training \\ and Education, Cenderawasih University, Papua, Indonesia. \\ Markus Ricky Rumansara, Department of Languages and Arts, Faculty of Teacher Training and Education, \\ Cenderawasih University, Papua, Indonesia.
}

Received: December 22, 2021

Accepted: Janaury 24, 2022 Online Published: January 25, 2022

doi:10.5430/wjel.v12n1p129

URL: https://doi.org/10.5430/wjel.v12n1p129

\begin{abstract}
Biak is a Papuan tribe inhabiting the Biak Island, to the north of mainland Papua. This tribe has a type of folksongs called wor. Using Nöth's theory of metaphor and Haley's 9 categories of the hierarchy of human perceptions, this study aimed to explore the metaphorical expressions (metaphiers) found in 17 wor lyrics through metapherein process to find their metaphands, and to identify the human perceptions in the metaphiers seen through the 9 categories. The study found that the Biak tribe expresses their concerns about life and its complexity as discovered in the metaphors found in the metaphands: happiness, deliverance, caring, preservation of culture, respect, longing for homeland, perseverance, youth reminder, evil spirit, inhumane treatment to others, fighting spirit, dexterity, vigilance, strong family support, 'heaven', the ritual for luck, and creator of the universe. Most languages in the world must have similar universal metaphors, but their meanings may be universal or local as is true with wor lyrics. Haley's 9 categories were found. The categories observed are: Being was found 4 times in 4 lyrics; Cosmos was observed 2 times in 2 lyrics; Energy was found 2 times in 2 lyrics; Terrestrial was discovered 2 times in 2 lyrics; Object was found 2 times in 2 lyrics; Living was not found in these present data; Animate was not observed in these current data either; and Human was observed the most, 5 times in 5 lyrics.
\end{abstract}

Keywords: wor, Biak tribe, folksongs, metaphorical expressions, metaphier, metaphand, metapherein

\section{Introduction}

Almost all tribal peoples around the world, including the Papuans, have traditional folksongs for a variety of reasons, ranging from celebrating births to mourning losses. With the rapid advancement of global telecommunications, traditional communities who are unable to keep up will undoubtedly be left behind, losing all of their centuries-old histories, such as folk melodies, or possibly succumbing to obscurity. Folksong messages are frequently presented using schemes and tropes such as metaphors.

Folksong research is generally lacking in Papua. However, studies on lamenting lyrics have been conducted. Munaba, a lamenting ceremony for kings and other high-status individuals conducted through songs and dances in Waropen, Papua, was examined by Dharmojo (2005). Modouw (2010) conducted a similar study for the Sentani tribe known as Helaehili in Jayapura, concentrating on the functions and roles of tribal women from a feminist perspective. Yikwa (2018) conducted a third study among the Lany people in the Papua mountains on lamentation lyrics known as Lendawi. The varieties and roles of lamentation were studied in this research. Fatubun (2021) presented an article at the first ISSHE international Seminar in Kendari, Southeast Sulawesi, based on data from the Lendawi lyrics. There have been no studies on metaphorical expressions on these Biak folksong lyrics named Wor, aside from studies on these lamenting songs. Therefore, studies on metaphorical phrases in the lyrics of the Biak wor or any other Papuan folksongs are needed to be conducted.

\subsection{Research Significance}

This research is significant in a number of ways: (a) it aids in the preservation of folksongs so that they do not perish. Although these wor folksongs are still well-preserved through regular performances, both in traditional tribal rituals 
and public performances, they need to be studied in order to figure out what the metaphorical expressions mean; (b) it helps reveal meanings, wisdom, and messages in the metaphorical expressions. The Biak tribe is one of Papua's most evolved tribes, with a lot of philosophical tribal ideas, ideals, and concepts that impact Papuans in general in their socio-political lives, as evidenced through folk songs and other folk literary works. This is done to assist individuals in comprehending current socio-political actions that may serve as indexes. (c) It could be the first study of wor metaphorical expressions employing Nöth's theory of metaphor and Haley's 9 categories of human perception hierarchy.

\subsection{Research Questions}

The research questions were (a) What are the meanings of the metaphorical expressions contained in wor lyrics? and (b) To which of Haley's 9 categories of the hierarchy of human perceptions do the expressions belong?

\subsection{Research Objectives}

The study's objectives were to (a) investigate and explore the meanings of metaphorical phrases found in wor lyrics, and (b) identify and explain the categories of human perceptions in the metaphorical expressions based on Haley's 9 categories of the hierarchy of human perceptions.

\section{Literature Review}

\subsection{What is Metaphor?}

Metaphors are very common in any language but especially prominent in poetry (Vansina, 1985) of which songs are a part. Lakoff and Johnson (1980) mentioned that metaphor is a device of the poetic imagination and the rhetorical flourish - a matter of extraordinary rather than ordinary language. Newmark as quoted in Karnedi (2011, Cruse, 2006) mentions that metaphor is the realization of combining words, from colocation to textual order. Kövecses (2015) discusses 13 common sources of metaphors and 13 common target domains in his Where Metaphors Come From identifying common sources like the human body, health and illness, animals, plants, et cetera and 13 target domains such as emotion, desire, morality, thought, politics, human relationships, et cetera. Nordquist (2019) mentions that there are about fourteen types of metaphor, for example, absolute metaphor, complex metaphor, conceptual metaphor, conventional metaphor, et cetera. Mentioned here also are two other types of metaphors: creative metaphor, usually explored in the literary texts, mainly poetry, including songs, and conventional metaphors, used in daily conversations to express feelings and emotions (Knowles and Moon, 2005).

\subsection{What is Wor?}

A folk song usually has simple, short, with repetitive lyrics (except some ballads), is not particularly artfully high-level, is created by ordinary folk, and represents shared emotions about life (Sing, 1985). This can be seen in most folk songs. Usually, these songs reflect on shared cultural heritage, happiness, and pain/sadness, or certain social problems, anxiety about this life, belief in a higher power, acts of heroism, kindness, love saying, beauty, sadness, separation, customs, etc (Kóczy, 2018). Usually, the melody is simple and natural because the emotion of the song comes from the people's own environment. Folk song is an art that ordinary people can participate as members of society in it. Wor is certainly very similar and has those characteristics.

In many civilizations, one can observe that there is a coherence between dance, music, and belief in mythology, history, legend, or even epic and this is seen in these folk songs too. Because this wor is still well conserved, it will survive for a long period of time into the future and can even be modified to bring new different styles.

Rumansara (2003) defines wor as an activity closely tied to traditional ceremonies. In the past, Rumansara (2003) mentions that wor was a medium used by the Biak people to be close to their supreme deity called Manseren Nanggi. They also believe in Koreri, an era of abundance and happiness where there is no more poverty, suffering, and death (Fatubun, 2017, 2021a). Konor and Mon are terms used for messengers of Manseren Nanggi, the king of the Koreri (Mansoben, 2003; Hanita, 2019).

Wor is also a number of songs sung by the people in traditional ceremonies. In this situation, people sing and dance at the same time. Throughout their tribal life, the Biak people are required to carry out these wor, particularly the munara, the ceremony according to their functions in life. In general, there are ten types of wor (Fatubun and Rumansara, 2021) and this present study deals with the analysis of the metaphorical expressions in wor lyrics.

\subsection{Previous Studies}

There have been a number of studies related to the issue under discussion. Sriyono, et al (2015) discusses The Cultural Codes in Oral Literature of Biak, Papua, a study aiming to describe the cultural codes in the Biak oral 
literature, using Umberto Eco's semiotic approach. Rumbekwan's study (2019), Peristiwa-Peristiwa Perang Suku/Tradisional di Pesisir Utara Papua, is a study about the historiography reconstruction of life dynamic of the tribes in the northern part of Papua around the $15^{\text {th }}$ century through the $19^{\text {th }}$. The study talks about civil wars among tribes in Papua, and the Biak people's domination during that era in the territory from Cenderawasih Bay to the north of the Papuan coast. In a study entitled Biak Numfor Oral Prose, Fatubun (2017) reported an anthological study on the Biak oral folk stories. He also wrote (2017) "An Archetypal Reading the Manarmakeri Myth from Biak, Papua: Its Development Implications and Political Significance" discussing the most important myth in Biak mythology i.e. Manarmakeri in its development implications and political significance both among the Biak people and the political life among Papuans in general. In his Archetypes in Biak Folktales: Characters, Symbols, and Concepts, Fatubun (2021) discusses the most important characters, symbols, and concepts that influence the life of the Biak people found in the stories. These archetypal characters, symbols, and concepts are also mentioned and used in wor folksong lyrics. These are only a few of the studies on Biak that are not directly related to this present study.

The following are some studies on metaphors of song lyrics but not folksongs. In fact, they are modern songs. Lestari (2017) employed Lakoff and Johnson's metaphor theory for her study Metaphors in the Song Lyrics of Greenday. She found that the songwriter uses more ontological metaphors in the lyrics. Aisah (2010) conducted the study Metafora Dalam Lagu Iwan Fals Yang Bertemakan Kritik Sosial, the title of the study. The goal of this study was to determine the 9 most prevalent metaphorical expressions found in song lyrics, as well as the most prevalent source domain. The findings demonstrate that metaphor is the most prevalent metaphorical expression in Iwan Fals' song lyrics. This study also discovered that the source domain of animals is the most prevalent in Iwan Fals' song. Pertiwi (2007) conducted a study titled Metaphor on the Song Lyrics of Enka in Besuto Hitto Daizenshu. The goal of this study was to identify metaphors found in Enka's song lyrics and the context in which they were used. She discovered the following metaphors: life is a journey, suffering is an uphill road, happiness is a growing flower, and so on. In addition, the metaphor's context is linked to the Japanese environmental experience. The ten backgrounds of employing the metaphor in Japanese culture are: (1) the proximity of Japanese people to nature, (2) the concept of impermanence 'mujo,' and (3) the sensitivity 'aware.'

\section{Research Methodology}

\subsection{The Data}

This is an ethnographic investigation (Ary; Jacobs; Sorensen; and Walker, 2014). From February 2021 through the end of March 2021, this investigation took roughly 3 (three) weeks. The Biak Numfor Regency was chosen because it is home to the majority of Biak's indigenous people, and the elderly who are knowledgeable about the region's history, culture, beliefs, arts, and, particularly, wor, would be valuable sources. Interviews, observations, and documents were used to gather information.

Because the second researcher is a native speaker of the Biak language, he conducted the interviews, while the rites and performances were observed and recorded using a tablet. The second researcher then transcribed and coded the data. Some of the information was gathered from both offline and online documents. A total of 23 wor was collected. Only 17 wor are used in this article: (1) WSP; (2) WAM; (3) WAO; (4) WMM; (5) WMO; (6) WIB; (7) WWD; (8) WMH; (9) WAS; (10) WMT; (11) WWG; (12) WKL; (13) WDE; (14) WNW; (15) WNG; (16) WMR; (17) WYS (Note: $\mathrm{W}=$ wor; the second letter is the first letter of the first word in the Biak language title; the third letter is the first letter of the first word in the English title). In the Data Presentation section, the codes and complete titles are presented. To improve validity, the researchers used triangulation in the following areas: 1) sources; 2) time; 3) theories; 4) researchers; and 5) methodologies (Alwasilah, 2008). The data is presented in this format for the convenience of presentation and reading: 1 . Song title; 2 . Metaphier (metaphorical statement, not the entire song); 3. Metaphand (Meaning); 4. Haley's metaphor category. Each item has a brief description. The Discussion section contains explanations.

\subsection{The Methods}

According to Nöth (in Fatubun, 2012), the word metaphor comes from the Greek word 'metapherein' (meta=across; pherein=to carry), which means 'to carry across.' Metaphor necessitates the identification of a target object, as well as the identification of another object that reshapes the target object by being carried over to it. Metaphand (tenor) is the target object, which is akin to Saussurean signified; metaphier (vehicle) is the item transported over to do the defining, altering, coloring, or modifying. Metapherein, like Saussurean signification, is the act of defining, altering, coloring or modifying. With these explanations in mind, the lyrics were studied to separate the metaphands from the metaphiers, resulting in a conclusive lyric interpretation. 
Because there are multiple possibilities, the possible metaphands are those that are appropriate for the context and appear in the lyrics. The metaphands are based on ideas from Cirlot's A Dictionary of Symbolism (1962) and Biedermann's Dictionary of Symbolism (trans. James Hulbert, 1992), as well as the lyric's traditional cultural setting. Because the metaphands are a synthesis of my perception of their significance in the context, this sort of metapherein combines what Nöth calls static aspect (1995) and dynamic aspect (1995) (ibid).

Going through a process of metaphor signification to develop specific meanings from a work of literature, or the micro world formed by literary people is actually making new texts. If necessary, these new texts may also undergo additional signification. "Texts are a system of forces institutionalized at some expense by the dominant culture, not an ideal cosmos," writes Said (in Richter, 1989:1036).

Using Halley's universal metaphors in the hierarchy of human perceptions that can influence the imagery in metaphors (Chink et al, 1980; Wahab, 1990; Wahab, 1991) as seen in the table below, this article examines the metaphorical expressions in wor lyrics.

Table 1. Halley's hierarchy of human perceptions

\begin{tabular}{|l|l|l|}
\hline Category & Examples & Characteristics \\
\hline BEING & Truth, beauty & Being \\
\hline COSMOS & Sun, earth & Use space \\
\hline ENERGY & Light, wind & Move \\
\hline SUBSTANCE & Hydrogen, gas & Sluggish \\
\hline TERRESTRIAL & Mountain, sea & Spread out \\
\hline OBJECT & Minerals (rock, ball) & Break \\
\hline LIVING & Flora & Grow \\
\hline ANIMATE & Fauna & Walk, run \\
\hline HUMAN & Man, woman & Think \\
\hline
\end{tabular}

These universal categories are understood as being found in any language at all because they have always been there. With BEING on top, all the other categories are understood as being a sub-category of the category above it. For example, the category ANIMATE is the sub-category of Living. And so on. Metaphorical expressions in wor lyrics are identified based on these categories.

According to Kövecses $(2015,2010)$ "Apart from some sporadic studies (such as Aitchison, 1987; Koller 2004; Kövecses, 2005; Semino, 2008; Benczes, 2010, 2013), the issue of context-induced metaphorical creativity has not been systematically investigated." This study, therefore, has tried to explain the metaphorical expressions found in wor lyrics in connection with the context in which they are found.

\section{Data Presentation}

\subsection{Metaphiers and Their Metaphands in the Wor Lyrics}

This article examines the metaphorical expressions based on Nöth's theory of metaphor and Haley's 9 categories of the hierarchy of human perceptions as mentioned above. In this data presentation, a brief description of each wor is given. The metaphiers are in boldface.

(1)

a. WSP: Sarai ramo ramo eya (Palm Leaves)

b. Metaphier: Sarai ramo beyar korer, korero ryama

c. Metaphand: deliverance

d. Halley's Metaphor Category: Being

Description: This is a song about palm leaves, which are thought to signify a happy existence - a life like in paradise. This is quite similar to the word 'korer,' which means 'happy life.' 'Korer' belongs to Halley's metaphors in the Being category because it is an idea.

a. WAM: Aryo Binggone (My Dear Sister) 
b. Metaphier: Aryo Binggone, ibyeriso worringgoma

c. Metaphand: caring, responsibility, patience, sacrifice

d. Halley's Metaphor Category: Human

Description: This song is about a 'binggone' sister's child's haircut ritual, which is witnessed by her brother (s). 'Binggon(e)' is made up of two words: 'bin,' which means 'female,' and 'nggon,' which comes from the term 'aingyon,' which means 'stick,' with the suffix /e/ indicating the presence of a person. Thus, 'binggon(e)' means 'support woman,' implying that if a woman's brother is in trouble, this 'binnggon(e)' sister will come to the brothers' rescue. Because 'binggone' is a sister, it belongs to the Human group in Halley's metaphors.

(3)

a. WAO: Aryo Naeko (Oh My Brother)

b. Metaphier: Byubero Budaya Byak ine isuri iryewen, Ro Papua sup ineno

c. Metaphand: owner of the culture

d. Halley's Metaphor Category: Terrestrial

Description: This folksong is an invitation, especially to Biak academics, to propagate Biak culture in order to keep it alive. In this land of Papua, which stretches across the Pacific Ocean and is mostly mountains, lowlands, and small islands like Biak, inhabited by Melanesian tribes with dark skin and curly hair, is referred to as 'Ro Papua Sup Ine (no). Because 'Ro Papua Sup Ine (no)' refers to a location, it falls under Halley's Terrestrial category.

(4)

a. WMM: Man Yeja (My Bird)

b. Metaphier: A man yeja manbeforo ... / Papua sup o marin yeja

c. Metaphand: the outpouring of emotion for homeland

d. Halley's Metaphor Category: Terrestrial

Description: The song is about a bird that has flown back to Papua, the singer's dreamland.

'Papua supo marin' translates as 'Papua is a dream island, a location full of blessings, ancestral land, and a land without distress.' 'Papua sup marin' refers to Papua as the home of many of the island's tribes. 'Papua sup marin' is classified as Terrestrial in Halley's metaphor hierarchy.

(5)
a. WMO: Mak deki Kyankondo (O Star Rise to Reign)
b. Metaphier: Mandep kar mandoreko dorek arwo/Sampari mak iwa deki kyankondo
c. Metaphand: joyful situation and happiness
d. Halley's Metaphor Category: Cosmos

Description: Venus, the rising star of Sampari, is the subject of this morning hymn. It would be amazing, says the singer, if the star could ascend to reign. In the Biak oral tradition of the Manarmakeri tale, the phrase 'Sampari Mak iwa,' or 'Morning Star' (Venus), refers to the Makmeser, or Morning Star (Fatubun, 2017; Fatubun, 2021a; Hanita, 2017; Kamma, 1972). In Halley's classifications, the star 'Mak Sampari' is classified as a Cosmos metaphor.

(6)
a. WIB: Isaibo (Boiling/Blazing)
b. Metaphier: Woo... ryokira .... isaibo-isaibo/..., ro bero sinan sya bepono.../ sireb ai maremi ryokira isaibo, isaibo
c. Metaphand: perseverance; strength
d. Halley's Metaphor Category: Object

Description: The singer appears to be asking the Biak people to listen to the echoes that remind them of their forefathers, as the 'sireb', the principal musical instrument in a wor performance keeps on echoing.

The musical instrument beaten to accompany songs and dances in wor performances is known as the 'Sireb' or 'tifa.' As a musical instrument, it belongs to the Object metaphor in Halley's hierarchy, which is denoted by the word 
'sireb.'

(7)

a. WWD: Woiyo wo, yabe wor bara orisyun (Dear, I didn't sing until the sun went down)

b. Metaphier: imbe kabore, yabe wor bara orisyun/dobe robe row be au

c. Metaphand: old age, reminding people of their youth

d. Halley's Metaphor Category: Cosmos

Description: According to the singer, he did not begin singing until after the sun had set. He's sorry he didn't succeed. 'Orisyun' is made up of two unrelated words: 'ori,' which means 'sun,' and 'syun,' which means 'entry.' The term 'orisyun' then refers to the sun's descent (entry). In Halley's hierarchy, we can see that the metaphor in this work is a Cosmos metaphor.

(8)
a. WMH: Myunbo Daryaro (He Killed, Then Passed by)
b. Metaphier: Daryar kakin bindam iwa Myunbo daryaro
c. Metaphand: inhumane treatment to someone (a woman)
d. Halley's Metaphor Category: Human

Description: Because of the killing, the situation in this song is a little scary. This is a war incident in which a foreign woman was captured as war loot forcibly. 'Bindam' means 'foreign woman,' and it is a derogatory term. In Halley's hierarchy, the metaphor in this song belongs to the Human category.

(9)
a. WAS: Amyas Ampero (Sagu Palm Frond)
b. Metaphier: amyas ampero, besaki bekun rum iwabara ... / sumber mamun ...
c. Metaphand: fighting power
d. Halley's Metaphor Category: Energy

Description: This is also a battle song in which a 'mambri,' or knight, is required to execute deeds similar to those performed by knights in order to safeguard his territory. The word 'mamun' signifies 'war' in the Biak language. The word 'mamun' is used to depict a dangerous situation in this folksong. In Halley's metaphor hierarchy, one may see the metaphor category Energy metaphor.

(10)

a. WMT: Mamuno Kumunnya (The War We Are Facing)

b. Metaphier: Naeko wobe mamuno

c. Metaphand: the attitude of vigilance and preparedness to face life reality

d. Halley's Metaphor Category: Energy

Description: This wor serves as a warning to others that war is on its way, and it is not far away. 'Mamun' means 'war' or 'battle' in the traditional meaning. Here, the wor is more akin to a piece of life advice.

Based on Halley's hierarchy, the metaphor in this work belongs to the Being category.

(11)
a. WWG: Wos Refo (God's Word)
b. Metaphier: Sabumi wongge
c. Metaphand: respect for the ancestors
d. Halley's Metaphor Category: Human

Description: The wor teaches people that they must now believe in the Bible because their forefathers' faith and devotion are no longer valid. 'Sabumi' means respect for the ancestors who have passed on this new faith to them. The metaphor in this song is a Human metaphor in Halley's hierarchy, with the word 'Sabumi' as its defining feature. 

a. WKL: Kombroro-Kombrordo (Let Us Be Aware)
b. Metaphier: Aryawin manwen naneno
c. Metaphand: the power of evil or the appearance of the Devil
d. Halley's Metaphor Category: Human

Description: This wor serves as a reminder to individuals to stop using black magic and instead trust in the Bible's teachings. 'Manwen,' which means 'someone with black magic or evil power,' is thought to have evil power and has the ability to take someone's life without ever touching them physically. According to Halley's categories, the metaphor in this song belongs to the Human category.

(13)
a. WDE: Dou Arbur (Exorcist's song)
b. Metaphier: Weki waref ro dorie,,, sares Byakine
c. Metaphand: High respect
d. Halley's Metaphor Category: Object

Description: This wor invites a person to place one foot on a 'sares,' an ancient plate, as a welcome gesture. Antique artifacts such as old porcelain plates and bowls, the consequence of trade between people from East Asia, particularly the Chinese and Biak cultures, are referred to as 'Sares' by the Biak people. In Halley's hierarchy, the metaphor 'sares' in this song belongs to the Object group.

(14)

a. WNW: Nasasya (We Are Here)
b. Metaphier: Nasyaya Ngosnerayo ye
c. Metaphand: strong family support for a woman
d. Halley's Metaphor Category: Human

Description: This wor refers to a woman's relatives, particularly her brothers, providing support to her.

Traditional ceremonies must be performed for a mature married woman in the Biak community. As evidenced by the verb 'ngosnerayo,' which means 'we are here,' the metaphor in this song corresponds to the Human category in Halley's hierarchy.
a. WNG: Neno, Neno (God, God)
b. Metaphier: Neno, Neno, nene Nanggi yasya/Wadoi kwanso bin Byaki bin Ineno
c. Metaphand: Kingdom of Manseren, 'heaven'
d. Halley's Metaphor Category: Being

Description: This is a prayer for a mother who is having trouble giving birth to a child. The term 'Nanggi' means 'sky,' or 'heaven,' and thus belongs to the Being category in Halley's metaphor hierarchy.

(16)
a. WMG: Mami Wasama (God the Ruler of the Universe)
b. Metaphier: Manggawi yasya wado rwamuma/ mami wasama buk barakas soren
c. Metaphand: a ritual for good luck
d. Halley's Metaphor Category: Being

Description: This wor also functions as a prayer, requesting God to bless the sea with plenty.

Another name for Manseren Nanggi is 'Manggawi yasya.' This spirit is thought to be one of, and the most powerful, of the Biak people's six spirits. In Halley's metaphor hierarchy, this wor incorporates a Being metaphor, which is signified by 'Manggawi.'

1. WYS: Yen Saoneko (Saoneke Sand) 
2. Metaphier: Yen Saoneko-yen Saoneko/... neno nene Manseren Bebai Dado Kyondo

3. Metaphand: creator dan ruler of the universe

4. Halley's Metaphor Category: Being

Description: Yen Saoneko is a lovely white sand beach that the Biak people believe is a pristine, clean, and pure location for God to descend. People invite God to listen to their prayers by inviting Him to come down. 'Yen Saoneko' is a term in which 'Yen' means 'sand,' and 'Saoneko' means the location of the sand. The Great God, Manseren Nanggi, is also known as 'Manseren Beba(i).' In the Biak belief system, the highest deity is referred to as 'Manseren Beba(i). 'Manseren Bebai' falls within the Being category in Halley's metaphor categories.

\subsection{Discussion}

\subsubsection{The Metaphiers and Metaphands}

\subsubsection{About the Supreme Being (WMG, WYS)}

The supreme being is the subject of these two data. Manseren Nanggi, also known as Manseren Manggundi, the supreme being, and creator of the cosmos, is revered by the Biak people. This concept establishes that this spirit is in charge of the universe and everything within it just like God (Tresidder, 2011; Biedermann, 1994; Cirlot, 1971). In other words, the universe would not have existed if Manseren Nanggi had not existed. Furthermore, they think that Manseren Nanggi is the source of human life and that when people die, their spirits will be reunited with him.

Fatubun (2021:241; Hanita, 2019; Kamma, 1972) mentioned this deity under archetypal figures, although he placed it within the study of key notions. "Traditionally, this deity is thought to be Manarmakeri himself in the fable Manarmakeri," he writes. Manseren and Nanggi have taken on new meanings after the introduction of Christianity into the Biak people's lives. The name Manseren is only used to refer to the Christian God, but the word 'Nanggi' is used to refer to God's Kingdom or heaven. In truth, these two words are still used interchangeably when referring to God.

Another name for Manseren Nanggi is 'Manggawi yasya.' It is proper for mankind to seek his blessings because his might spans the entire globe. Biak people would usually perform a ceremony to this deity before going out to earn a living in order to gain adequate favors. A shaman would perform a'mawi' in the past as part of a ceremony to see how their luck would change when they went fishing or hunting. The Biak tribe and Manggawi used this ceremony as their only means of communication.

People would know what Manggawi intended and what they would get through this media channeling. They would go if the shaman claimed they would be lucky; otherwise, they would put it off. The seasonal Biak calculation was used to perform this ritual in specific months. According to this computation, there is just one 'wampasi' harvesting season per year, which takes place between May and July. Typically, the Biak people would harvest their crops during these months, while the sea tide was at its lowest, trapping a large number of easy-to-catch fish.

\subsubsection{About the Afterlife (WSP, WNG)}

The afterlife, which is also a major topic in Biak tribal culture, is addressed in these two data through metaphorical phrases. 'Korer' is about transitioning from the mortal old realm to the immortal new realm, where there are no longer any crimes or flaws, no distinctions between people, and everyone is the same. 'Korer' refers to the holy state, which is free of all defects. The Biak people believe that 'korer' refers to a place where one can remain silent while experiencing the incarnation, or the transition from one body to another (Tresidder, 2011; Biedermann, 1994; Cirlot, 1971).

When Fatubun (2017:162; Hanita, 2019; Fatubun, 2021; Kamma, 1972) discussed the most important Biak myth Manarmakeri, he said, "The Koreri is... an age where there is abundance, no more deaths, the dead will come back to life, and there is everlasting happiness." In tribal belief, 'Nanggi' alludes to the Kingdom of God, or heaven. This notion has been given a Christian interpretation and significance. Many Christian songs, as well as secular Biak songs, now include the word 'Manseren Nanggi.'

\subsubsection{The Carpe Diem Wor (WIB, WWD)}

In WIB data, the word 'Sireb' denotes impermanence. The wooden drum, known as 'Sireb,' is the main musical instrument used when people perform traditional Biak melodies like wor. Wood, animal skins, carvings, and honey water are among the elements used to create 'Sireb.'

A 'sireb' becomes a luxury and a high value in the Biak people's lives in the past, thus it must be well preserved. However, like an earthly object, 'sireb' cannot last indefinitely; over time, natural processes will cause parts or the Published by Sciedu Press 
entire entity to become corrupted. As a high-value cultural product, it should be preserved by teaching the next generation about it, because otherwise, it will all be extinct, corroded by time. It also represents man's strength, particularly during his performance, while also reminding people that, like the 'sireb,' they must do their best while they are still alive. There is a carpe diem message here.

In WWD data, 'Orisyun' refers to the time before dark, or dusk when the sun is setting. In the four-season regions of the world, this represents a person's age, comparable to Fall. When night falls, wicked spirits of the dead, known as 'arbur,' begin to roam; as a result, elderly people should stay at home to avoid being disturbed by these evil spirits. The Biak people also think that during the dark hours, people should refrain from engaging in difficult tasks that may endanger others' lives, and that working at night may unknowingly bring misfortune.

'Orisyun,' which means 'dusk,' figuratively signifies old age and reminds people of their youth, making them regret not having used it wisely during their youth, another carpe diem message like the preceding wor. These poetic lyrics are reminiscent of renowned English poems such as Richard Henry S.'s 'The Flight of Youth,' Robert Herrick's 'To Daffodils,' and Ali Hasjmi's 'Menyesal' (Regret).

\subsubsection{About Women (WAM, WMH, WNW)}

A 'binnggone' sister in the WAM data has a significant role in Biak culture, however, women are excluded from inheritance. A 'Binnggon(e)' is said to play a crucial role because she will be the hope for all of her brothers. When both parents have died, the 'binnggon(e)' will take over her siblings' care. When her brothers have a disagreement or fight, she will be the mediator. Caring, responsible, patient, and willingness to sacrifice are attributes that define a 'binggone.' The siter's responsibility in this work is to do anything for the happiness and survival of her brothers.

The story is different from WMH data. A 'bindam', unlike a 'binggone,' had bad luck in the past. She could have come from any foreign place and become a member of the Biak community through bride price or piracy during the Hongi war (Rumbekwan, 2019). If she was successfully kidnapped from her native family by a certain gang, the term 'Bindam' was automatically applied to her. A 'bindam' was seen to be inferior. Even her basic human rights were disregarded, and she was treated as a 'binnggone.' Because some 'bindam' women were trapped in piracy, they were likely unable to converse with the 'binggone' women, adding to their anguish as 'bindam' women. The term 'bindam' refers to the inhumane treatment of a person, such as ostracization and treating her as inferior to others. Her 'bindam' position often restricted her rights, such as bringing forward ideas or participating in meetings. This situation is presently improving as a result of education.

Although the WNW data is still about women, it is now more generalized. It is difficult for women today, let alone in the past, to live in a patriarchal society. Support from a woman's family is extremely important in Biak tribal culture. If this is not the case, it is expected that the lady will have numerous troubles in her marriage and would be unhappy. These issues can emerge from her husband, her in-laws, or her husband's extended relatives. 'Ngosnerayo,' which means 'we are here,' is a forceful statement made by a group of individuals, particularly the woman's own family members, that they will stick by her and that no one will attempt to humiliate her.

Supportive and proud words like this make a woman who wants to marry feel safer and more confident in her life choices because she knows her family will embrace her decision. Furthermore, if she ever has the opportunity to perform her family's traditional rites for her children, her brothers will be involved in ensuring that the activities are carried out successfully so that her children would be blessed and have a better life. The Biak tribe follows a patriarchal structure, yet women are valued in their culture since the Biak people appreciate the significance of women, especially in human breeding.

\subsubsection{About War (WAS, WMT)}

These two pieces of information are about conflict and how the spirit of fighting in the past has been transformed into positive traits in the present. In the WAS data, war is associated with the notion of 'besaki bekun,' which means 'to light up and burn,' and refers to the same object, fire, which is a sign of fury or agony, burning and devouring all in its path. War is also related to machetes, which are used to cut wood and other materials, and it is a compelling situation in which there is a great deal of killing between two opposing groups. As a result,'mamun' represents a riveting circumstance in which there is bloodshed as a result of the battle.

The term "high spirit" or "fighting power" can refer to a group of people's unshakable determination or a symbol of destruction directed towards the adversary as a war victim.

The term 'mamun' denotes dexterity, ability, and ingenuity in preparing to protect oneself in tough situations, like as on a battlefield. Because there are no longer any wars, particularly tribal wars, as there once were, the high fighting 
spirit is now used to face life's realities.

Culturally, the Biak people in the past knew that 'mamun' was something that could not be seen but did exist, according to WMT data. As a result, all that was required, both mentally and physically, such as weapons and equipment, should be provided. 'Mamun' can strike at any time and without warning. Since 'mamun' has undergone a transition in meaning, it now denotes an attitude of awareness and ready to face every life situation, whether planned or unexpectedly, rather than the physical conflict as it did in the previous wor. It's more of a wise piece of life advice here.

\subsubsection{About Respect (WWG, WDE)}

The Biak people used to believe in ancestral spirits, according to their culture. 'Korwar' or 'Anfyanir' is a testament to ancestral spirits' existence, strength, and reverence. With the arrival of the Christian message, this type of belief was weakened and lost. Following the receipt of the new belief, the forefathers passed down the Bible from generation to generation in order to replace the old belief. These predecessors are the ones that gave birth to the Biak people, generating the first descendants. Since then, the majority of Biak people have converted to Christianity, and because they believe their forefathers were also Christians, they have acquired a new ancestral belief, Christianity. 'Sabumi,' which means 'ancestor,' is a sign of respect for the ancestors who have inherited them with this new religion, according to WWG data.

In the WDE data, the word 'sares,' which means 'ancient plate,' indicates another way to demonstrate respect for others. When a person is welcomed by being asked to place one foot on a 'sares,' an ancient plate, it denotes that the person has a high social status in the village and is well-liked by the locals. They think that by performing this welcoming rite, the person will be able to contribute to the betterment of their lives. This welcoming rite is now performed for all notable guests or visitors to the Biak community. The Biak people consider these 'sares' to be particularly essential elements in the bride prize.

People carrying a variety of' 'sares' of varying sizes, models, forms, and colors may be seen delivering the bride prize. Because 'sares' are not made locally, they have acquired a status of respect symbolism. This is quite similar to the adjacent Kei tribe in the Moluccas' southeast, who use the same object as well as old Portuguese cannons in their bride prizes. Because 'sares' are antique and expensive goods, they represent a great level of respect and honor. Placing one's foot on the 'sares' denotes that this object has a value equal to or greater than the 'sares'.

\subsubsection{About the Love for Homeland and Its Culture (WAO, WMM)}

The Biak people are being encouraged to maintain something, namely 'local culture,' so that it does not become extinct or perish, according to this WAO data. In the WMM data, the word 'ro Papua sup ine' refers to the community that owns the culture that inhabits the western portion of Papua, particularly the younger generation today as a whole, to conserve and disseminate Biak culture such as wor. One other cultural example is the Biak people regard the son of either a mother's or a father's brother as a 'napirman karyer,' a demigod who deserves to be respected throughout his life. If respect is not shown, fury will follow; on the other hand, if respect is shown, blessings will be poured on the cousins, and this will continue for centuries.

'Papua supo marin' is a term that translates to 'Papua is a dream island, a place full of blessings, ancestral land, a land without distress.' The expression refers to a person's emotional outpouring when he or she misses the place from which he or she came. In real life, this statement alludes to his or her country, Papua, the Pacific Ocean's largest island. The island of Papua is divided into two parts: the eastern section is a sovereign nation, and the western part is made up of two Indonesian provinces. Papua is noted for its immense natural resources such as minerals, fauna, and flora, as well as tourist spots such as the Baliem valley and the Raja Ampat island as well as a wealth of marine resources. It was described as a "little heaven plummeting to earth" in an Indonesian song. The bird of paradise, serves as a reminder to all Papuans of the 'Papua sup marin,' Papua as the ancestral homeland of more than 250 tribes who have lived there since time immemorial.

\subsubsection{On Warning about Evil Spirit (WKL)}

Fatubun (2021) considers the character 'manwen' to be the most archetypal of the archetypal characters because she appears in seven of the 50 tales he investigated. Little boys were captured by the manwen to be eaten, a hamlet was terrified of the 'manwen' and forced to relocate, and so on. 'Manwen' is a component of the devil's form in Christianity, and it is against God's will. The 'manwen' is a symbol of evil power or the Devil's appearance (Tresidder, 2011; Biedermann, 1994; Cirlot, 1971), which runs counter to the Biak people's current beliefs. Psychoanalytically, 'manwen' can be described as the dark side of a person who abuses others. The Biak people regard the 'manwen' to be an outdated system of belief that should no longer exist in their lives as a civilization that has known the light of the 
Gospel. This wor serves as a reminder to the Biak people to continue to cling to the Bible for direction in their lives.

\subsubsection{Halley's Metaphor Categories}

The original version of this article included 20 folksongs, but each folk song might have multiple metaphorical meanings. Except for Substance, the folksongs contained all of Halley's criteria. Living and Animate are not present in this version of the article. Only 17 wor folksongs are included in this current form, each of which has only one metaphorical expression.

Table 2. Halley's Metaphor Hierarchy

\begin{tabular}{|c|c|c|}
\hline Category & Examples & Data \\
\hline BEING & $\begin{array}{l}{ }^{1} \text { Korer, }{ }^{2} \text { Nanggi, }{ }^{3} \text { Manggawi yasya, }{ }^{4} \text { Manseren } \\
\text { Bebai }\end{array}$ & $\begin{array}{l}\text { WSP, WNG, WMG, } \\
\text { WYS }\end{array}$ \\
\hline COSMOS & ${ }^{1}$ Sampari mak $;{ }^{2}$ orisyun; & WMO, WWD \\
\hline ENERGY & ${ }^{1}$ mamun $;{ }^{2}$ mamuno & WAS, WMT, \\
\hline SUBSTANCE & - & - \\
\hline TERRETRIAL & ${ }^{1}$ Ro Pариа sup ineno; ${ }^{2}$ Рариа sup o marin yeja; & WAO, WMM, \\
\hline OBJECT & ${ }^{1}$ sireb $;{ }^{2}$ sares & WIB, WDE \\
\hline LIVING & $\begin{array}{l}\text { (There are some in the original version of this } \\
\text { article) }\end{array}$ & \\
\hline ANIMATE & $\begin{array}{l}\text { (There are some in the original version of this } \\
\text { article) }\end{array}$ & \\
\hline HUMAN & $\begin{array}{l}{ }^{1} \text { Binggone, } \quad{ }^{2} \text { bindam, } \quad{ }^{3} \text { Sabumi; } \quad{ }^{4} \text { manwen; } \\
{ }^{5} \text { Ngosnerayo; }\end{array}$ & $\begin{array}{l}\text { WAM, WMH, WWG, } \\
\text { WKL, WNW }\end{array}$ \\
\hline
\end{tabular}

From the table above, one can see that the human perceptions in this tribe as seen in the metaphorical expressions produced by this tribe are wide, from the far away and abstract ideas found in the Being category down to the nearest concept, human. This stands to reason because this tribe lives on islands and it has been in contact with other tribes or other people from distant places for centuries, for example, the contact with the sultanate of Tidore (Hanita, 2019). A number of the concepts in the Being category in other sources are biblical in nature. In the Manarmakeri myth, there are a number of biblical allusions (Fatubun, 2017, 2021a, 2021b).

Kövecses (2015) states that there are two contexts that one can see in metaphors: The Local context and the global context. Both contexts are influenced by four determinant contexts which include (1) situational context, (2) discourse context, (3) conceptual-cognitive context, and (4) bodily context. This study, therefore, has tried to explain the metaphorical expressions found in wor lyrics in connection with the context in which they are found. Kövecses' concepts are not very different from Halley's hierarchy of human perceptions, and therefore the data presented have also shown similar ideas.

\section{Conclusion}

People convey their concerns about life and its complexity, like happiness, pain, despair, anxiety, belief, heroism, kindness, and so on, in oblique ways in wor lyrics, as in any other folk song lyrics, both traditional and modern. Happiness, deliverance, caring, patience, sacrifice, invitation to preserve culture, respect throughout life, blazing spirit, perseverance, reminding people of their youth, evil spirit, inhumane treatment, cleverness, a sense of brotherhood, vigilance to face life, the power of evil, family support, 'heaven', a ritual for luck, and ruler of the universe are just some of the metaphands that reflect these realities in the Biak society. These metaphands have been grouped under 8 general headings as shown above: About the Supreme Being (WMG, WYS), About the Afterlife (WSP, WNG), The Carpe Diem Wor (WIB, WWD), About Women (WAM, WMH, WNW), About War (WAS, WMT), About Respect (WWG, WDE), About the Love for Homeland and Its Culture (WAO, WMM), and On Warning about Evil Spirit (WKL).

Haley's categories of metaphor were found that except for Substance, Living, and Animate, the other categories were observed in the metaphiers in the lyrics: Being is found 4 times in 4 lyrics; Cosmos is observed 2 times in 2 lyrics; Energy is found 2 times in 2 lyrics; Terrestrial is discovered 2 times in 2 lyrics; Object is found 2 times in 2 lyrics; and Human is observed the most, 5 times in 5 lyrics. One can see that most categories in Halley's hierarchy of metaphor are present in the Biak folksongs. With more complete data, all categories may be found. Therefore, more 
research is needed to determine how far this tribe's human perceptions have progressed, in order to better understand why this tribe has become one of the most developed among the Papuan tribes. The more evolved a people's perceptions are, according to Halley's human perception hierarchy or Kövecses' two contexts with their four sub-contexts, the more developed they will be. Since this tribe lives on islands, a bigger one called Biak with other smaller ones, their accesses and contacts with other cultures have been made for centuries. These meetings with other civilizations have added to the development of perceptions of the world among the tribal people.

\section{References}

Aisah, S. (2010). Metafora Dalam Lagu Iwan Fals yang Bertemakan Kritik Sosial. Jakarta: University of Indonesia.

Alwasilah, C. (2008). Pokoknya Kualitatif. Jakarta: Pustaka Jaya.

Ary, D. J., Lucy, C., Sorensen, C., \& Walker, D. (2014). Introduction to Research in Education. Belmont: Wadsworth.

Biedermann, H. (1994). Dictionary of Symbolism. New York: Penguin Group.

Chink, M. K. L., Halley, M. C., \& Lunsford, R. F. (Eds.) (1980). Linguistic Perspective on Literature. London: Routledge and Kegan Paul.

Cirlot, J. E. (1971). A Dictionary of Symbols. London: Routledge.

Cruse, A. (2006). A Glossary of Semantics and Pragmatics. Edinburg: Edinburg University Press Ltd.

Cuddon, J. (1992). Dictionary of Literary Terms and Literary Theory. London: Penguin Books.

Dharmojo. (2005). Sistem Simbol dalam Munaba Waropen Papua. Jayapura: Rewamboina Production.

Fatubun, R. R. (2017). An Archetypal Reading the Manarmakeri Myth from Biak, Papua: Its Development Implications and Political Significance. Australian Journal of Basic and Applied Sciences, 11(9), 157-164. Retrieved from www.ajbasweb.com

Fatubun, R. R. (2020). Lendawi: The Multifunction Chants and Their Metaphorical Expressions Among the Lany Tribe In Papua. Proceedings of the First International Seminar Social Science, Humanities and Education, ISSHE. https://doi.org/10.4108/eai.25-11-2020.2306710

Fatubun, R. R. (2021a). Archetypes in Biak Folktales: Characters, Symbols, and Concepts. Linguistics and Culture Review, 5(1), 230-246. https://doi.org/10.21744/lingcure.v5n1.1483

Fatubun, R. R. (2021b). Biblical Allusions in Papuan Mythical Folktales and Their Effects on Material Culture Development for the Papuans. KnE Social Science, 144-159. https://doi.org/10.18502/kss.v5i7.9330

Hanita, M. (2019). Cita-Cita Koreri. Jakarta: Universitas Indonesia Publishing.

Kamma, F. C. (1972). Koreri. The Hague: Martinus Nijhoff.

Karnedi. (2011). Penerjemahan Metafora Konseptual dari Bahasa Inggris ke Bahasa Indonesia Studi Kasus Penerjemahan Buku Teks Bidang Ekonomi. Jakarta, Indonesia University Press.

Kócsy, J. B. (2018). Nature, Metaphor, Culture "Cultural Conceptualization in Hungarian Folksongs". Hungary: Springer.

Kovecses, Z. (2010). Metaphor: A Practical Introduction (2 nd ed.). Oxford: Oxford University Press.

Kövecses, Z. (2015). Where Metaphors Come From. New York: Oxford University Press. https://doi.org/10.1093/acprof:oso/9780190224868.001.0001

Lakoff, G., \& Johnson, M. (1980). Metaphors We Live By. Chicago: University of Chicago Press.

Lestari, W. (2017). Metaphors in the Song Lyrics of Greenday. Jakarta: Syarif Hidayatullah State Islamic University.

listiani, W., Rustiyanti, S., Sari, F. D., \& Peradantha. I. S. (2020). Desain Model Purwarupa Augmented Reality Patung Karwar 4.0 Sebagai Media Pembelajaran Seni Tradisi Biak Papua. Jurnal Budaya Nusantara, 3(2), 82-86. https://doi.org/10.36456b.nusantara.vol3.no2.a2529.

Mansoben, J. R. (2003). Sistem Politik Etnis Byak; Kajian tentang Pemerintahan Tradisional. Jurnal Antropologi Papua, 1(3). Jayapura: Balai Bahasa Papua

Modouw, W. Y. (2010). Introducing Helaehili, an Oral Poetry from Sentani, Papua. ATAVISME, 13(2), 149-160. https://doi.org/10.24257/atavisme.v13i2.126.149-160 
Nordquist, R. (2021). The Different Types of Metaphors. Retrieved August 27, 2021, from https://www.thoughtco.com/ways-of-looking-at-a-metaphor-1691815

NÖth, W. (1995). Handbook of Semiotics. Indianapolis: Indiana University Press.

Pertiwi, S. A. (2007). Analisis Metafora Pada Lirik Lagu Enka Dalam Besuto Hitto Daizenshu. Jakarta: University of Indonesia.

Richter, D. H. (Ed.). (1989). The Critical Tradition: Classic Texts and Contemporary Trends. New York: St. Martin's Press.

Rumansara, E. H. (2003). Transforamsi Upacara Adat: Wor Dalam Lingkaran Hidup Orang Biak. Humaniora, 15(2), 212-223. https://doi.org/10.22146/jh.789

Rumbekwan, A. (2019). Peristiwa-Peristiwa Perang Suku/Tradisional di Pesisir Utara Papua. Jayapura: IPS, FKIP, Universitas Cenderawasih.

Sing, H. B. (1985). A Study of Manipuri Meitei Folklore (Unpublished Ph.D. Thesis). Jalukbari, India: Gauhati University.

Tresidder, J. (2011). 1001 Symbols. London: Watkins Publishing.

Vansina, J. (1985). Oral Tradition as History. London: The University of Wisconsin Press.

Wahab, A. (1990). Butir-Butir Linguistik. Surabaya: Airlangga University Press.

Wahab, A. (1991). Isu Linguistik Pengajaran Bahasa dan Sastra. Surabaya: Airlangga University Press.

Yikwa, P. (2018). Lendawi (the Lanny Tribe Lamentation): Its Structure, Types, and Socio-cultural Values. Unpublished Master's Thesis. Jayapura: PBS, FKIP, Universitas Cenderawasih.

\section{Copyrights}

Copyright for this article is retained by the author(s), with first publication rights granted to the journal.

This is an open-access article distributed under the terms and conditions of the Creative Commons Attribution license (http://creativecommons.org/licenses/by/4.0/). 